\title{
TEKNIK PENGGUNAAN ALAT TANGKAP TAJUR (Hook and lines) DI RAWA BANJIRAN SUNGAI MUSI, SUMATERA SELATAN
}

\author{
Ahmad Sayani \\ Teknisi Litkayasa pada Balai Riset Perikanan Perairan Umum, Mariana-Palembang \\ Teregristasi I tanggal: 13 Pebruari 2006; Diterima setelah perbaikan tanggal: 12 September 2006; \\ Disetujui terbit tanggal: 5 Pebruari 2007
}

\section{PENDAHULUAN}

Sungai Musi merupakan Sungai terpanjang di Sumatera Selatan, memiliki 9 buah anak sungai. (Menon dalam Gaffar, 1997). Kegiatan penangkapan ikan di perairan rawa banjiran di lakukan sepanjang tahun. Ada beberapa jenis alat tangkap yang digunakan, antara lain tajur (hook and lines), karena harga murah dan mudah didapatkan (Gambar 1). Kegiatan penangkapan berlaku sepanjang tahun, puncak musim berlangsung pada musim kemarau (bulan Maret sampai dengan September). Alat tangkap tajur dengan umpan anak katak atau cacing atau anakan ikan hanya digunakan untuk menangkap ikan gabus. Ikan gabus (Channa striata Bloch) adalah salah satu jenis ikan bernilai ekonomis yang digemari oleh masyarakat karena mempunyai tekstur daging yang putih dan tebal serta cita rasa yang khas. Dengan tekstur daging yang tebal dan putih serta tidak mempunyai duri selip ikan gabus merupakan jenis ikan yang paling banyak digunakan untuk produk olahan seperti kerupuk, pempek, dan berbagai makanan lain. Kondisi ini menyebabkan masyarakat nelayan menjadi tertarik untuk menangkap ikan gabus dengan menggunakan alat tangkap tersebut. Menurut anonim (2002), ikan gabus dewasa makanan utamanya adalah udang, serangga, katak, cacing, dan ikan.

\section{BAHAN DAN METODE}

Bahan untuk alat terdiri atas:

- tali nilon ukuran No.100 sampai dengan 300.

- Pancing ukuran No. 10 sampai dengan 13.

- 1 unit perahu ukuran panjang $400 \mathrm{~cm}$ lebar 80 sampai dengan $100 \mathrm{~cm}$.

- Satang atau galah panjang $400 \mathrm{~cm}$.

- Dayung panjang $150 \mathrm{~cm}$.

- Sanggi (serok).

- Pisau.

- Ember.
Bahan untuk umpan terdiri atas:

1. Anak katak.

2. Cacing.

3. Anakan ikan.

\section{Prosedur Kerja Alat}

Stick atau galah bambu $\varnothing 0,5 \mathrm{~cm}$ dan panjang 1,5 sampai dengan $2 \mathrm{~m}$ yang berguna untuk mengikatkan tali nilon atau pancing. Setelah itu, tajur dipersiapkan 500 buah disusun di dalam perahu. Tajur tersebut selanjutnya diberi umpan semua. Pagi hari atau sore hari kira-kira pukul 06.00 atau 16.00 tajur yang telah disiapkan lalu dipasang atau dideder di lokasi yang telah ditentukan (Gambar 2). Pada waktu tengah hari (kira-kira pukul 12.00) atau sore hari (pukul 16.00) maka tajur tadi diperiksa satu persatu, tujuan untuk mengetahui umpan sudah habis atau telah dimakan dan mendapatkan ikan gabus. Kalau umpan tersebut habis, maka tajur tadi diberi lagi umpan yang baru. Pada keesokan hari tajur diperiksa kembali demikian dan seterusnya. Hasil tangkapan kemudian dikumpulkan dalam sangkar penampungan yang terbuat dari bilah-bilah bambu yang dianyam dengan rotan atau tali nilon yang dibentuk empat persegi panjang, setelah itu ikan hasil tangkapan siap dijual pada pedagang pengumpul (Gambar 3).

\section{HASIL DAN BAHASAN}

Hasil tangkapan ikan gabus di perairan umum tergolong yang paling tinggi di antara jenis-jenis ikan yang lain, yaitu sekitar $14,2 \%$ dari hasil total tangkapan di Waduk Kedungombo (Kartamihardja, 1994). Hasil tangkapan ikan gabus dengan menggunakan tajur selama pengamatan di rawa banjiran berkisar antara 2,5 sampai dengan $10 \mathrm{~kg}$ per 500 alat per hari, bobot rata-rata per individu antara 50 sampai dengan $245 \mathrm{~g}$. Pada saat rawa mulai surut atau memasuki musim kemarau penghasilan nelayan meningkat dibandingkan pada musim sebelumnya yaitu dari 10 sampai dengan $300 \mathrm{~kg}$ per 500 alat per bulan. (Tabel 1). 
Tabel 1. Hasil tangkapan tajur kg per 500 alat per bulan, tahun 2004

\begin{tabular}{ccccccccccccc}
\hline No. & Jan. & Peb. & Mar. & April & Mei & Juni & Juli & Agst. & Sep. & Okt. & Nop. & Des. \\
\hline 1. & 60 & 70 & 210 & 265 & 210 & 240 & 240 & 90 & 90 & 50 & 10 & - \\
2. & 60 & 75 & 150 & 250 & 270 & 290 & 280 & 90 & 95 & 45 & 10 & - \\
3. & 90 & 90 & 150 & 250 & 210 & 300 & 270 & 70 & 110 & 40 & 15 & - \\
4. & 105 & 65 & 270 & 290 & 240 & 285 & 280 & 80 & 100 & 30 & 10 & - \\
\hline
\end{tabular}

Dari hasil pengamatan dilapangan bahwa nelayan hanya dapat menghasilkan ikan gabus yang dapat lebih banyak pada bulan Maret sampai dengan September.

\section{KESIMPULAN}

1. Hasil tangkapan tajur dengan umpan anak katak atau cacing adalah ikan gabus.

2. Tajur efektif dioperasikan pada rawa banjiran.

3. Hasil tangkapan tertinggi pada bulan Juni yaitu $300 \mathrm{~kg}$ per 500 alat bulan, sedangkan tangkapan terendah pada bulan Nopember yaitu $10 \mathrm{~kg}$ per 500 alat per bulan.

\section{DAFTAR PUSTAKA}

Anonim. 2002. Snakeheads of the World. Htt: ///www. Fishace. Demon. Co. Uk/snake/zastriat. Html. (4 April 2002).

Gaffar A. K. 1997. Perikanan perairan umum di daerah aliran Sungai Musi Sumatera Selatan. Makalah Simposium Perikanan Indonesia II. Ujung Pandang 2-3 Desember 1997. 1-13 hal.

Kartamihardja E. S. 1994. Biologi reproduksi populasi ikan gabus Channa striata di Waduk Kedungombo. Buletin Perikanan Darat. 12 (2): 113-119.

Kottelat, M., J. A. Whitten, S. N. Kartikasari, \& S. Wiryoatmodjo. 1993. Freshwater fishes of western Indonesia and Sulawesi. Periplus Edition (H. K.) Ltd. Jakarta. 221 p. 


\section{Lampiran 1. Bentuk alat tangkap Tajur}

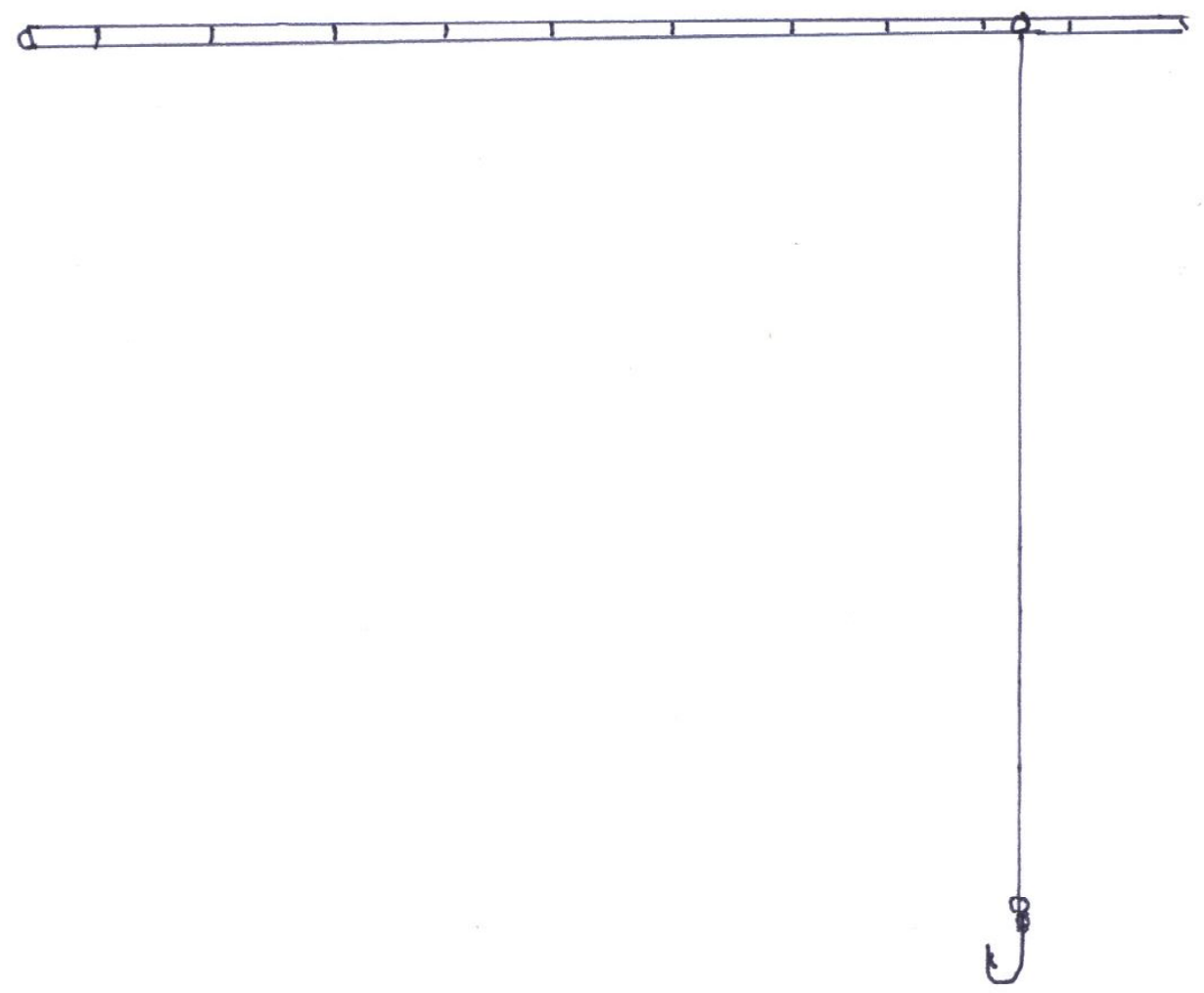

Lampiran 2. Pemasangan atau pendederan alat tangkap tajur (hook and lines)

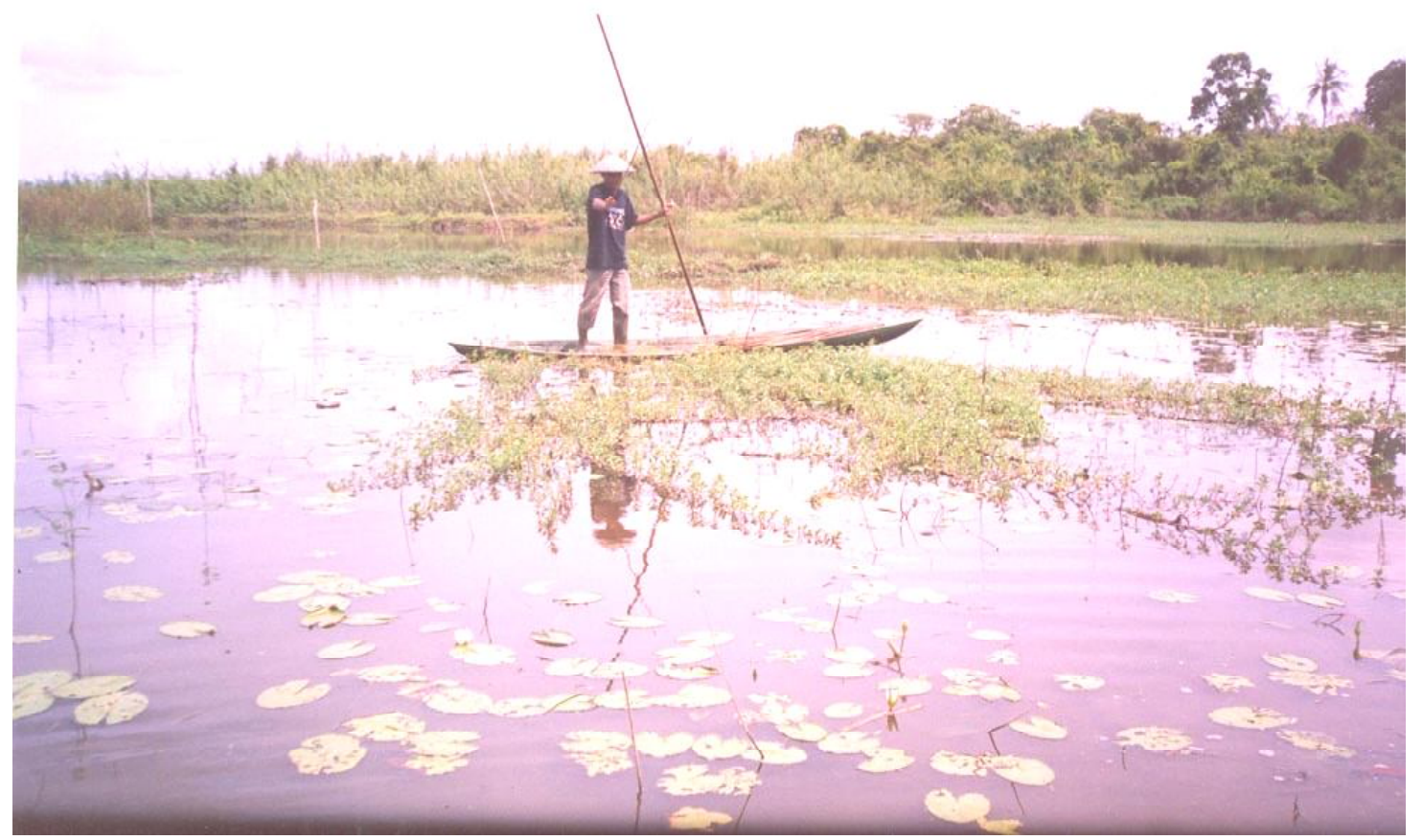


Lampiran 3. Hasil tangkapan yang siap untuk dijual ke pengumpul ikan

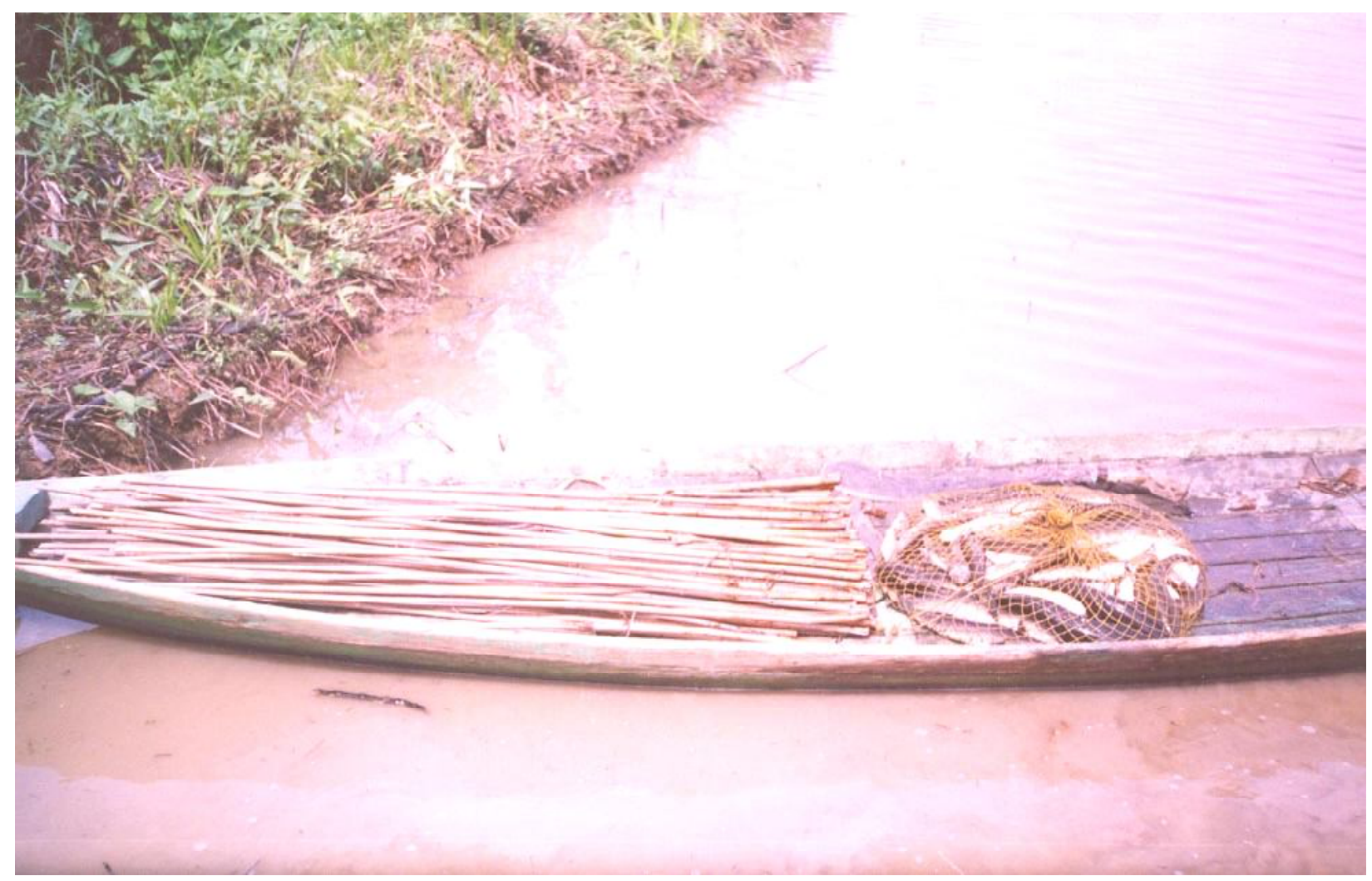

